\title{
ANALISIS KARAKTERISTIK SIFAT KIMIA TANAH PADA LAHAN ORIGINAL PRA TAMBANG DAN LAHAN REVEGETASI PASCA TAMBANG BATU BARA DI PT TRUBAINDO COAL MINING KABUPATEN KUTAI BARAT PROVINSI KALIMANTAN TIMUR
}

\author{
Irfan Efendi ${ }^{1}$, Kholik Hidayah ${ }^{2}$, Zuhdi Yahya $^{2}$ dan Legowo Kamarubayana ${ }^{2}$ \\ ${ }^{1}$ Kehutanan, Fakultas Pertanian, Universitas 17 Agustus 1945 Samarinda, Indonesia. \\ ${ }^{2}$ Dosen Fakultas Pertanian, Universitas 17 Agustus 1945 Samarinda 75124, Indonesia. \\ E-Mail: irfan@untag-smd.ac.id
}

\begin{abstract}
ABSTRAK
Analisis Karakteristik Sifat Kimia Tanah Pada Lahan Pra dan Pasca Tambang Batubara di PT Trubaindo Coal Mining, Kabupaten Kutai Barat, Provinsi Kalimantan Timur. Tujuan penelitian ini adalah Untuk mengetahui karakteristik sifat kimia tanah pada lahan original pra tambang dan pada lahan revegetasi pasca tambang yang mengalami ketidaknormalan petumbuhan tanaman dan yang pertumbuhannya normal.Metode penelitian menggunakan metode purposive sampling yaitu pengambilan sampel yang didasarkan pada pertimbangan umur pengolahan lahan revegetasi pasca tambang dengan jenis tanaman Jabon (Anthocephalus cadamba). Pengambilan sampel tanah mengikuti metode standar Food and Agriculture Organization (FAO 1976) yaitu pada kedalaman 0-30 dan 30-60 cm pada setiap titik pengamatan, selanjutnya dianalisis sifat kimia tanahnya dan akan dibandingkan. Analisis sifat kimia tanah dilakukan di Laboratorium Tanah Pusat Studi Reboisasi Hutan Tropika Humida (PUSREHUT), Fakultas Kehutanan, Universitas Mulawarman Samarinda.

Berdasarkan hasil analisis sifat kimia tanah pada lahan original pra tambang dilokasi penelitian pada umumnya mempunyai nilai $\mathrm{pH}$ yang sangat rendah berkisar antara $\left(4,12-3,71 \mathrm{H}_{2} \mathrm{O}\right), \mathrm{C}$-organik sedang hingga sangat rendah berkisar antara $(2,42-0,22 \%)$, nitrogen rendah hingga sangat rendah berkisar antara $(0,18-0,05$ $\%$ ), fosfor sangat rendah berkisar antara (4,27-0,22 ppm), kalium rendah hingga sangat rendah berkisar antara (0,15-0,07 meq/100 gr), natrium sangat rendah berkisar antara (0,02-0,01 meq/100 gr), magnesium rendah hingga sangat rendah berkisar antara $(0,25-0,03 \mathrm{meq} / 100 \mathrm{gr})$, kalsium sangat rendah berkisar antaraa $(0,14-$ $0,04 \mathrm{meq} / 100 \mathrm{gr})$, kapasitas tukar kation sangat rendah berkisar antara (9,96-3,04 meq/100 gr), kejenuhan basa sangat rendah berkisar antara $(8,11-2,08 \%)$ dan kejenuhan aluminium yang tinggi hingga sangt tinggi berkisar antar $(56,59-72,26 \%)$.

Adapun sifat kimia tanah pada lahan revegetasi pasca tambang dilokasi penelitian baikpada tanaman yang mengalami ketidaknormalan pertumbuhan dan yang pertumbuhanya normal tidak memiliki perbedaan yang signifikan kecuali magnesium yang mempunyai nilai tergolong sedang dan kejenuhan basa mempunyai nilai yang tergolong tinggi pada tanaman yang pertumbuhanya normal,berikut rinciannya nilai $\mathrm{pH}$ berkisar antara $\left(4,09-4,53 \mathrm{H}_{2} \mathrm{O}\right)$, C-organiK berkisar antara $(0,44-1,27 \%)$, nitrogen berkisar antara $(0,08-0,10 \%)$, fosforberkisar antara (0,22-2,50 ppm), kalium berkisar antara (0,11-0,15 meq/100 gr), natrium berkisar antara (0,00-0,02 meq/100 gr), magnesium berkisar antara (0,15-1,89 meq/100 gr), kalsium berkisara antara $(0,05-$ $1,29 \mathrm{meq} / 100 \mathrm{gr})$, KTK berkisar antara (4,50-6,12 meq/100 gr), dan kejenuhan aluminium berkisar antara $(23,76-76,83)$.
\end{abstract}

Kata kunci : Pertambangan Terbuka, Revegetasi, Analisis, Sifat Kimia Tanah.

\begin{abstract}
Analysis of Soil Chemical Properties Characteristics in Coal Pre and Post Mining Land in PT Trubaindo Coal Mining, West Kutai Regency, East Kalimantan Province. The purpose of this study was to determine the characteristics of soil chemical properties on the original pre-mining land and on postmining revegetation land that experienced abnormal growth of plants and normal growth. The research method uses purposive sampling method, namely sampling based on consideration of post-mining revegetation land processing age with Jabon plant species (Anthocephalus cadamba). Soil sampling follows the standard method of the Food and Agriculture Organization (FAO 1976), namely at 0-30 and 30-60 cm
\end{abstract}


depths at each observation point, then analyzed the soil chemical properties and will be compared. Analysis of soil chemical properties was carried out at the Land Laboratory of the Humida Tropical Forest Reforestation Study Center (PUSREHUT), Faculty of Forestry, Mulawarman University, Samarinda.

Based on the results of the analysis of soil chemical properties in the original pre-mining land in the research location generally have very low $\mathrm{pH}$ values ranging from $\left(4.12-3.71 \mathrm{H}_{2} \mathrm{O}\right)$, moderate to very low $\mathrm{C}$-organic ranges $(2.42-0,22 \%)$, low to very low nitrogen ranging from $(0.18$ to $0.05 \%)$, very low phosphorus ranging from (4.27 to $0.22 \mathrm{ppm})$, low to very low potassium ranging from $(0.15$ to $0.07 \mathrm{meq} / 100$ gr), very low sodium ranging from (0.02-0.01 meq/100 gr), low to very low magnesium ranging from $(0.25-0.03$ meq/100 gr), calcium very low ranging between $(0,14-0,04$ meq/100 gr), very low cation exchange capacity ranging from (9,96-3,04 meq/100 gr), very low base saturation ranging between $(8,11-2.08 \%)$ and high aluminum saturation up to high levels ranging between (56.59-72.26\%).

As for the chemical properties of soil in post-mining revegetation land in a research location both on plants that experience growth abnormalities and those that grow normally do not have significant differences except magnesium which has a moderate value and alkaline saturation has a relatively high value in normal growing plants, the following details $\mathrm{pH}$ values range from $\left(4.09-4.53 \mathrm{H}_{2} \mathrm{O}\right)$, C-organiK ranges between $(0.44-1.27 \%)$, nitrogen ranges from $(0.08-0.10 \%)$, phosphorus ranges between $(0,22-2,50 \mathrm{ppm})$, potassium ranges $(0,11$ $0,15 \mathrm{meq} / 100 \mathrm{gr})$, sodium ranges from $(0,00-0,02 \mathrm{meq} / 100 \mathrm{gr})$, magnesium ranges between $(0,15-1.89 \mathrm{meq} /$ $100 \mathrm{gr})$, calcium is between $(0.05-1.29 \mathrm{meq} / 100 \mathrm{gr})$, CEC ranges from (4.50 to $6.12 \mathrm{meq} / 100 \mathrm{gr})$, and aluminum saturation ranges between (23.76-76.83).

Key words : Open Mining, revegetation, analysis, soil chemical properties.

\section{PENDAHULUAN}

Penambangan batu bara dengan
metode penambangan terbuka menyebabkan degradasi lahan, dengan terjadinya kerusakan sifat fisika, kimia dab biologi tanahnya, untuk itu diperlukan suatu upaya agar tanah tidak semakin terdegradasi, dengan cara kegiatan revegetasi yang merupakan salah satu teknologi rehabilitasi lahan rusak yang diakibatkan aktivitas manusia. Tujuan utama rehabilitasi lahan bekas tambang melalui revegetasi adalah menciptakan percepatan suksesi penutupan lahan oleh vegetasi yang mapan, efek katalis revegetasi ini diharapkan melalui perubahan kondisi di bawah tajuk (meningkatnya lengas tanah, mengurangi temperatur, dan lain-lain, meningkatkan struktur vegetasi menuju tingkat klimak, dan menghasilkan lapisan seresah organik dan humus pada tahuntahun awal pertumbuhan tanaman), revegetasi akan meningkatkan kecepatan perkembangan keragaman genetik dan biokimia pada lahan terdegradasi, kondisi tanah yang merupakan perpaduan sifat-sifat fisika, kimia dan biologi menjadi faktor yang menentukan keberhasilan revegetasi lahan pasca penambangan, sedangkan fungsi tanah sendiri adalah sebagai reaktor lingkungan dan media tumbuh tanaman.

Evaluasi kegiatan diperlukan untuk mengukur keberhasilan kegiatan revegetasi yang telah berjalan dalam upaya merehabilitasi dan memulihkan lahan yang rusak, hasil pelaksanaan evaluasi diperlukan untuk memberi rekomendasi dan bahan masukan guna perbaikan pelaksanan kegiatan rehabilitasi lahan pada masa yang akan datang, evaluasi kegiatan dapat dilakukan dengan cara melihat keberhasilan tumbuh tanaman (persentase tumbuh) dan kesehatan tanaman (persentase sehat) Permenhut (2009), selain itu dapat juga melakukan pendekatan melalui kegiatan penilaian sumberdaya tanah, pendekatan penilaian sumberdaya tanah telah banyak mengalami perkembangan dengan melibatkan berbagai fungsi tanah secara holistik, tidak hanya aspek produktivitas lahan saja, untuk itu kegiatan penilaian memerlukan tolok ukur yang dapat menggambarkan kecenderungan umum perubahan kondisi tanah selama 
dimanfaatkan, salah satu tolak ukur penilaian tersebut adalah mengetahui sifat kimia tanahnya.

Evaluasi mengenai sifat kimia tanah merupakan proses pendiagnosaan masalah keharaan dalam tanah serta menentukan jenis dan jumlah unsur hara yang diperlukan, salah satu cara yang sering digunakan dalam menilai sifat kimia tanah adalah melalui pendekatan dengan analisis tanah atau uji sampel tanah, secara umum uji tanah adalah suatu kegiatan analisis kimia di laboratorium yang sederhana, cepat, murah, tepat, dan dapat diulang (reproduceable) untuk menduga ketersediaan unsur hara, uji tanah dalam arti luas yaitu menyangkut aspek-aspek interpretasi, evaluasi dan penyusunan rekomendasi pupuk dari hasil uji tanah serta pengambilan sampel tanah. Tujuan Penelitian adalah: Untuk mengetahui karakteristik sifat kimia tanah pada lahan original pra tambang dan pada lahan revegetasi pasca tambang yang mengalami ketidaknormalan petumbuhan tanaman dan yang pertumbuhannya normal.

\section{METODA PENELITIAN}

\subsection{Tempat dan Waktu}

Pengambilan data penelitian dilakukan di areal lahan revegetasi pasca tambang batubara PT Trubaindo Coal Mining di Blok 05 Ex Pit 3000, Blok 03 Ex Pit 6800 dan Blok 12 Ex Pit 4500 serta lahan original pra tambang di Blok 33, Blok 05, Blok 03, Blok 14 Pit 3000,
Blok 14 Pit 7000, Blok 18 dan Blok 35. Pada bulan Juli-September 2018.

\subsection{Bahan dan Alat}

Bahan penelitian ini adalah contoh tanah lahan revegatasi pasca tambang batu bara PT Trubaindo Coal Mining yang berumur 2 tahun di Blok 05 Ex Pit 3000 dan umur $>3$ tahun diBlok 03 Ex Pit 6800 dan Blok 12 Ex Pit 4500 serta lahan original pra tambang diBlok 33, Blok 05, Blok 03, Blok 14 Pit 3000,Blok 14 Pit 7000, Blok 18 dan Blok 35.

Alat yang digunakan dalam pengambilan data, antara lain peta lokasi, LV strada untuk transportasi, GPS, software (autocad dan msoffice), kompas, laptop, cangkul, sekop, parang, plastik sampel, label, meteran, alat tulis dan kamera.

\subsection{Metode Penelitian}

Metode penelitian menggunakan metode purposive sampling yaitu pengambilan sampel yang didasarkan pada pertimbangan umur pengolahan lahan revegetasi pasca tambang meliputi lahan revegetasi pada umur 2 tahun di Blok 05 umur $>3$ tahun di Blok 03 dan 12 dengan jenis tanaman Jabon (Anthocephalus cadamba) adapun pada pada lahan original pra tambang selain diambil ada blok yang sama dengan lahan revegetasi diambil juga pada blok-blok yang sudah ditentukan.

Metode pengambilan sampel tanah mengikuti metode standar Food and Agriculture Organization (FAO 1976) yaitu pada kedalaman 0-30 dan 30-60 $\mathrm{cm}$ pada setiap titik pengambilan conto tanah. 


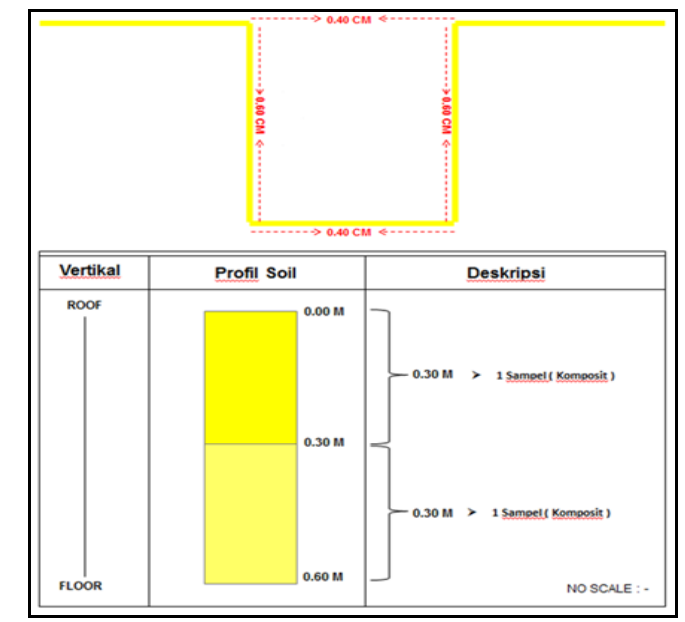

Gambar 1. Metode Pengambilan Contoh Tanah

Analisis sifat kimia tanah dilakukan di Laboratorium Tanah Pusat Studi Reboisasi Hutan Tropika Humida (PUSREHUT), Fakultas Kehutanan, Universits Mulawarman Samarinda, dan kreteria penilaian sifat kimia tanah mengunakan Petunjuk Teknis Evaluasi Kesuburan Tanah dari Balitanah Bogor (2005).

\subsection{Metode Pengumpulan Data}

Prosedur dalam penelitian ini dilakukan dengan empat tahapan, adapun tahapan-tahapn tersebut adalah tahapan pra lapangan, tahapan lapangan, tahapan pasca lapangan dan tahapan penyusunan laporan berikut penjelasanya :

\subsubsection{Tahapan Pra-Lapangan}

Pada tahapan ini yang dilakukan pertama adalah penyusunan proposal penelitian, Perijinan dan kelengkapan administrasi lainnya. Kedua kajian pustaka, kegiatan ini merupakan tahapan awal yang berguna untuk mengetahui peneliti-peneliti terdahulu mengenai kegiatan reklamasi pasca tambang batubara, ini berguna sebagai referensi dilakukannya penelitian, sehingga sebelum dilakukan pendataan di lapangan, peneliti mampu menginterpretasikan terlebih dahulu sebelum ke lapangan. Adapun interpretasi awal pada tahapan ini berdasarkan kajian pustaka adalah bahwa salah satu penyebab utama tanaman revegetasi pada lahan pasca tambang yang mengalami ketidaknormalan pertumbuhan disebabka oleh media tumbuhnya yaitu tanahnya yang mengalami degradasi, dimana tanah yang terdegradasi menunjukkan penurunan atau memburuknya sifatsifat tanah pada suatu lahan, baik sifatsifat fisik, kimia mapun biologi.

\subsubsection{Tahapan Lapangan}

Pada tahapan ini merupakan realisasi dari interpretasi tahapan pralapangan, Berdasarkan interpretasi awal tersebut, hal pertama yang dilakukan adalah observasi lapangan, kedua penentuan lokasi penelitian dan ketiga metode pengambilan sampel tanah, berikut penjelasanya :

a. Obsevasi lapangan

Observasi lapangan merupakan peninjauan untuk mengenali medan dan kondisi lapangan dan pengamatan langsung kelapangan terhadap objek pengamatan, adapun objek pengamatan spesifik dilakukan kepada lahan-lahan rehabilitasi yang terdapat tanaman revegetasi yang mengalami ketidaknormalan pertumbuhan, dikarenakan tanaman yang mengalami ketidaknormalan pertumbuhan terindikasi 
media tumbuhnya yaitu berupa tanah yang terdegradasi.

b. Penentuan lokasi penelitian

Penentuan lokasi penelitian disesuaikan dengan kebutuhan perusahaan, berdasarkan hasil diskusi dengan manajemen perusahaan penelitian diarahkan pada Blok-Blok selatan dari konsesi IUP PT Trubaindo Coal Mining yaitu di lahan revegetasi pasca tambang diBlok 05 Ex Pit 3000, Blok 03 Ex Pit 6800 dan Blok 12 Ex Pit 4500 serta lahan original pra tambang diBlok 33, Blok 05, Blok 03, Blok 14 Pit 3000, Blok 14 Pit 7000, Blok 18 dan Blok 35.

c. Metode pengambilan sampel tanah

Metode pengambilan sampel tanah merupakan unsur utama dalam peneliitan ini, yang dituntut untuk keakuratan data baik secara kualitatif maupun kuantitaif, karena keakuratan data yang diambil akan mempengaruhi hasil akhir penelitian ini, Berikut penjelasan proses metode pengambilan sampel tanah tersebut :

Pengambilan sampel tanah dilakukan dengan metode purposive sampling yaitu pengambilan sampel didasarkan pada pertimbangan umur pengolahan lahan revegetasi pasca tambangdan metode komposit, mengambil sampel tanah sebanyak $1 \mathrm{~kg}$ dari kedalaman inteval (0-30) $\mathrm{cm}$ dan (30-60) cm pada masing-masing Blok penelitian, pengambilan sampel mengikuti metode standar Food and Agriculture Organization (FAO 1976). Intensitas pengambilan sampel terkait dengan jumlah titik pengambilan sampel untuk penelitian awal ini menyesuaikan dengan kesepakatan manajemen perusahaan yaitu mengambil satu titik pengambilan sampel pada setiap Blok yang telah di tentukan. Untuk lahan original pra tambang dipilih lokasi yang masih original yang dipastikan belum terganggu dari kegiatan pertambangan dan masyarakat sekitar.
Untuk lahan revegetasi pasca tambang dipilih lahan yang tanaman revegetasinya mengalami ketidaknormalan pertumbuhan misalnya tanaman kerdil, riap tinggi dan diameter tidak sesuai umurnya, daun berwarna kuning, rotok dan tanaman banyak yang mengalami kematian. Kegiatan pengambilan sampel tanah dimulai dengan membersihkan permukaan dan sekitar tempat pengambilan sampel tanah seperti sisa kotoran daun dan semak. Kemudian tanah digali dengan cangkul membuat lubang kurang lebih lebar 40 $\mathrm{cm}$ dan dalam $60 \mathrm{~cm}$ sehingga membetuk suatu profil tanah berbentuk vertikal, setelah itu diukur menggunakan meteran dan diberi tanda untuk batas interval pengambilan sampel yang ditentukan, setelah itu sampel tanah diambil menggunakan cangkul dan sekop,selanjutanya sampel tanah dimasukan kedalam kantong pelastik, diikat dan diberi lebel, kemudian mengambi gambar sebagai dokumentasi, ini dimaksudkan untuk memudahkan penulis untuk menunjukan kepada pembaca, agar dapat melihat kenampakan-kenampakan fisik dari profil tanah yang dibuat pada penelitian ini, merekam atau recording titik penelitian menggunakan GPS, untuk memudahkan agar ketika diperlukan kembali titik penelitian mudah dicari, terakhir sampel dikirim untuk dianalisis ke Laboratorium Ilmu Tanah Pusat Studi Reboisasi Hutan Tropika Humida Universitas Mulawarman Samarinda.

\subsubsection{Tahapan Pasca-Lapangan}

Kegiatan yang dilakukan pada tahapan ini adalah mengabungkan data dari kajian pustaka dan dari data penelitian yang didukung dari hasil analisis Laboratorium, dan ditetapkan kriteria penilaian sifat kimia tanahnya menggunakan Petunjuk Teknis Evaluasi Kesuburan Tanah dari 
Balitanah Bogor (2005).

\section{HASIL PENELITIAN DAN PEMBAHASAN}

\subsection{Lokasi PT Trubaindo Coal Mining} Lokasi Penelitian secara administratif berada pada daerah Kecamatan Muara Lawa dan Betian Besar, Kabupaten Kutai Barat, Provinsi Kalimantan Timur, Secara koordinat geografis terletak pada $115300^{\prime} 00^{\prime \prime}$ - 155
51'30' BT, 0 27'44" - 0 51'41'" LS. PT

Trubaindo Coal Mining memiliki perjanjian kontrak karya dengan pemerintah Indonesia,konsesi tambang batubara seluas kurang lebih 23,000 ha.Untuk mencapai lokasi penelitian tersebut dari Kota Samarinda menuju kantor PT TCM site Adong, Kecamatan Muara Lawa, Kabupaten Kutai Barat, dapat menempuh perjalanan darat menggunakan roda empat kurang lebih 8 jam.

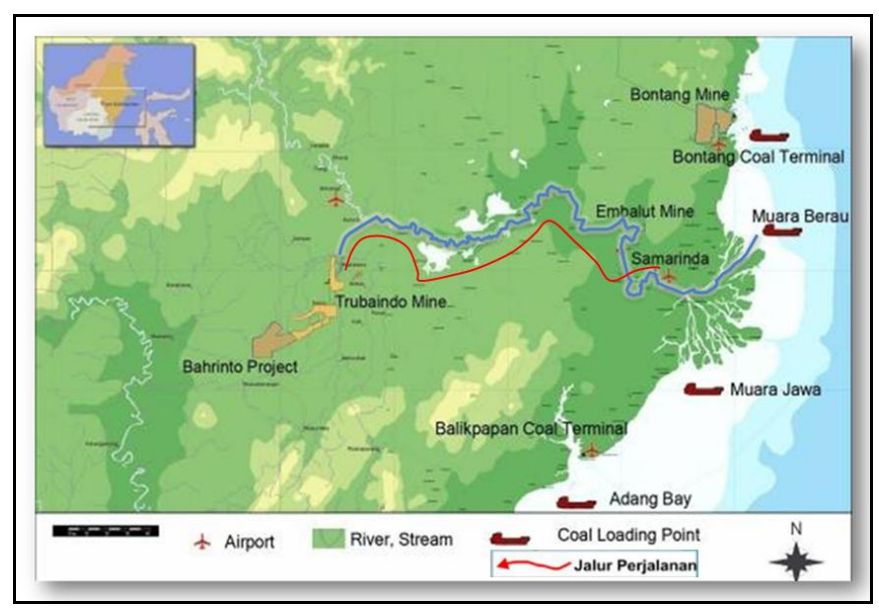

Gambar 1. Lokasi Kesampean Daerah Penelitian, Tanpa Skala.Sumber : Peta Konsesi PT TCM BEK, Website:itmg,co,id

\subsection{Iklim dan Curah Hujan}

Berdasarkan data iklm daerah kabupaten kutai barat yang bersumber dari Dinas pangan, tanaman pangan dan horikulutra karakteristik iklim Kabupaten Kutai barat termasuk dalam kategori iklim tropika humida, dengan rata-rata curah hujan tertinggi terdapat pada bulan April dan terendah di bulan Agustus serta tidak menunjukkan adanya bulan kering atau sepanjang bulan dalam satu tahun selalu terdapat sekurang-kurangnya tujuh hari hujan.

\subsection{Fisiografi}

Fisiografi Kutai Barat dapat dikelompokan menjadi delapan yaitu:
Alluvial Jalur Kelokan, Rawa-rawa, Lembah, Teras-teras, Dataran, Perbukitan dan Pegunungan, Bentuk lahan dominan adalah daerah dataran (38\%), perbukitan $(22 \%)$ dan pegunungan $(32 \%)$.

\subsection{Kondisi Geologi}

Secara geologi Kabupaten Kutai Barat terbagi dalam 14 formasi yaitu: formasi Haloq-Batu Kelau, Ujoh Bilang, Balikpapan, batu Ayau, Golok, Haloq, Kampung Baru, Kelinjau, Kuaro, Meragoh/ Meliat, Pemaluan, Pulau Barang, Tanjung dan Tuyudan, Beragam formasi ini terbentang beragam di sepanjang Kutai Barat, Hal ini menunjukkan bahwa kondisi geologi di 
daerah ini relatif beragam yang menandakan perbedaan jenis batuan penyusunnya serta morfologi wilayahnya.

\section{Jenis Tanah}

Jenis-jenis tanah yang terdapat di Kabupaten Kutai Barat menurut Soil Taxonomi USDA tergolong ke dalam jenis tanah : Ultisol, Entisol, Histosol, Incepticol dan Mollisol, atau bila menurut Lembaga Penelitian Tanah Bogor terdiri dari jenis tanah Podsolik, Alluvial, Andosol dan Renzina, Adapun pada wilayah penelitian tergolong kedalam jenis tanah Ultiol.

Sifat Kimia Tanah Berdasarkan Jenis Tanah Pada Wilayah Penelitian

Menurut Hardjowigeno (2003), Ultisol mempunyai sifat kimia yang kurang baik yang dicirikan oleh kemasaman tanah yang tinggi dengan $\mathrm{pH}$ $<5$, kandungan bahan organik tanah rendah sampai sedang, kandungan hara $\mathrm{N}, \mathrm{P}, \mathrm{K}, \mathrm{Ca}, \mathrm{Mg}$ dan $\mathrm{Mo}$ rendah, Kapasitas tukar kation (KTK) kecil dari $24 \mathrm{me} / 100 \mathrm{~g}$, Sebaliknya kelarutan Al, $\mathrm{Mn}$, dan Fe sering tinggi, sehingga sering meracun bagi tanaman, hal itu disebabkan oleh tingkat pelapukan yang sudah lanjut serta curah hujan yang tinggi, sehingga unsur hara tercuci ke lapisan bawah.

Kemasaman Tanah $(\mathrm{pH})$ dan Kejenuhan Aluminium

Pengolahan dari data Kemasaman Tanah $(\mathrm{pH})$ dan Kejenuhan Aluminium yang telah didapatkan dilapangan menghasilkan nilai seperti yang tersaji pada tabel dibawah ini.

Tabel 1. Perbandingan Nilai Kemasaman Tanah $(\mathrm{pH})$ dan Kejenuhan Aluminium Antara Lahan Original

\begin{tabular}{|c|c|c|c|c|}
\hline \multirow{3}{*}{ No } & \multicolumn{2}{|l|}{ Lapansan } & \multirow{2}{*}{ DI- } & \multirow{2}{*}{ kejemilham } \\
\hline & \multirow{2}{*}{ kode } & \multirow{2}{*}{$\begin{array}{c}\text { internal } \\
\text { (cin) }\end{array}$} & & \\
\hline & & & -120 & $\%$ \\
\hline 1 & \multirow{2}{*}{ BL335B2 (ORP. 3000$)$} & $0-30$ & $3.93(5 M)$ & $63.68(5 T)$ \\
\hline 2 & & $30-60$ & $3.92(5 M)$ & $70.48(5 T)$ \\
\hline 3 & \multirow{2}{*}{ BLOSSB1 (ORP - 3000$)$} & $0-30$ & 3.>1 (SM) & $59.15(T)$ \\
\hline 4 & & $30-60$ & $3.74(5 M)$ & $66.95(5 T)$ \\
\hline 5 & \multirow{2}{*}{ BLO3SBI (ORP.6800) } & $0-30$ & $3.74(5 \mathrm{M})$ & $62.97(S T)$ \\
\hline$\sigma$ & & $30-60$ & $3.83(5 M)$ & $65.50(5 T)$ \\
\hline > & \multirow{2}{*}{ BL14SBZ (ORP-7000) } & $0-30$ & $3.76(5 M)$ & $74.16(5 T)$ \\
\hline 8 & & $30-60$ & $3.92(5 M)$ & $72.81(5 T)$ \\
\hline 9 & \multirow{2}{*}{ BL14SBZ(ORP. 3000$)$} & $0-30$ & $3 .>7(s M)$ & $56.59(T)$ \\
\hline 10 & & $30-60$ & $4.12(5 \mathrm{M})$ & $62.89(5 T)$ \\
\hline 11 & \multirow{2}{*}{ BL18SB2(OR) } & $0-30$ & 3.93 (SM) & $61.47(5 T)$ \\
\hline 12 & & $30-60$ & $3.83(5 M)$ & $60.25(7)$ \\
\hline 13 & \multirow{2}{*}{ BL35SB2(OR) } & $0-30$ & $3.80(5 M)$ & $60.20(T)$ \\
\hline 14 & & $30-60$ & $3.89(5 M)$ & $72.26(5 T)$ \\
\hline
\end{tabular}

Keterangan : OR (Lahan Original Pra tambang), SM (Sangat Masam), T (Tinggi),ST (Sangat Tinggi)

Tabel 2. Perbandingan Nilai Kemasaman Tanah (pH), Kejenuhan Aluminium, Tinggi dan Diameter Antara Lahan Revegetasi

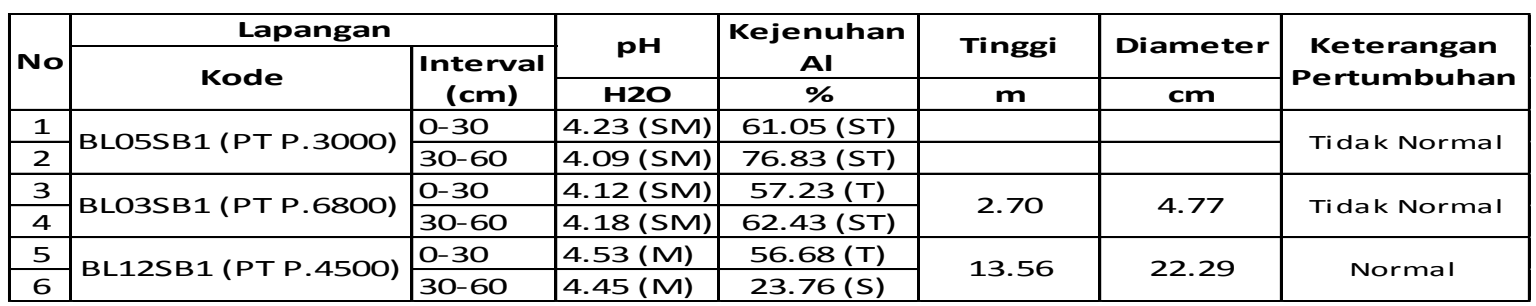

Keterangan : PT (Lahan Revegetasi Pasca Tambang) M (Masam), SM (Sangat Masam), S (Sedang), T (Tinggi), ST (Sangat Tinggi)

Berdasarkan hasil analisis sampel tanah di Laboratorium Tanah Pusat Studi
Reboisasi Hutan Tropika Humida Uiversitas Mulawarman Samarinda, baik 
pada kedalaman 0-30 maupun 30-60 cm menurut Petunjuk Teknis Evaluasi Kesuburan Tanah dari Balitanah Bogor (2005) nilai $\mathrm{pH}$ pada lahan original pra tambang kesluruhan tergolong sangat masam degan nilai $(3,71-4,12)$ dan nilai kejenuhan aluminium tergolong tinggi sampai sangat tinggi dengan nilai berkisar antara (59.15-74.16 \%), perbandingan nilai kemasaman tanah $(\mathrm{pH})$ dan kejenuhan aluminium antara lahan original pra tambang dapat dilihat pada tabel 2.

Adapun pada lahan revegetasi pasca tambangnilai $\mathrm{pH}$ pada lahan revegetasi pasca tambang Blok 03 dengan umur tanaman > 3 tahun dan Blok 05 dengan umur 2 tahun yang mengalami ketidaknormalan pertubuhan tanaman, baik pada kedalaman 0-30 maupun 30-60 $\mathrm{cm}$ menurut Petunjuk Teknis Evaluasi Kesuburan Tanah dari Balitanah Bogor (2005) tergolong sangat masam yaitu dengan nilai $\mathrm{pH}(4,09-4,23)$. Sedangkan pada Blok 12 dengan pertumbuhan tanaman yang normal dan dengan umur tanaman > 3 tahun yaitu tergolong masam dengan nilai $\mathrm{pH}$ (4,45-4,53), meski berbeda golongan dan mempunyai umur tanaman yang sama nilai $\mathrm{pH}$ pada blok 03 dan blok 12 diatas tidaklah jauh berbeda hanya berkisar antara $(4,12-$ 4,53).

Adapun kejenuhan aluminium pada lahan revegetasi pasca tambang tergolong tinggi sampai sangat tinggi, yaitu berkisar antara (56.68-76.83\%), kecuali pada blok 12 yang tergolong sedang dengan nilai (23.76 \%) pada kedalaman 30-60 cm. Akan tetapi menurut peneliti nilai yang tergolong sedang tersebut bukanlah penyebab tanaman jenis Jabon (Anthocephalus cadamba) dapat bertahan hidup selain masih tegolong sedang yang menurut Balitanah Bogor (2005) belum termasuk kondisi terbaik untuk tanaman, yang justru kondisi terbik berada pada golongan rendah sampai sangat rendah yaitu dengan nilai (20-5 \%) dan juga jika dilihat dari data hasil analisis sampel tanah pada lahan original pra tambang karakteristik sifat kimia tanah keseluruhan untuk kejenuhan aluminium semuanya tergolong tinggi sampai sangat tinggi yang mana tanaman jenis Jabon (Anthocephalus cadamba) mampu bertahan hidup dan berkebang biak, ini menunjukan tanaman jenis Jabon (Anthocephalus cadamba) toleran terhadap karakteristik sifat kimia tanah yang ekstirm seperti yang sudah dijelaskan diatas, perbandingan nilai kemasaman tanah $(\mathrm{pH})$ dan kejenuhan aluminium antara lahan revegetasi pasca tambang.

Kemasaman tanah adalah besarnya kandungan ion $\mathrm{H}^{+}$yang terdapat di dalam tanah, reaksi tanah yang masam disebabkan oleh curah hujan yang tinggi yang mengakibatkan basa-basa mudah tercuci, di samping itu hasil dekomposisi mineral aluminium silikat akan membebaskan ion aluminium, ion tersebut dapat diserap oleh koloid tanah, dan bila dihidrolosis akan menyumbangkan ion $\mathrm{H}^{+}$, akibatnya tanah menjadi masam, selain itu, penyebab lainnya adalah proses pelapukan bahan organik yang menghasilkan asam organik dan anorganik turut menyumbangkan reaksi asam pada tanah.

Aldd adalah kadar Aluminium dalam tanah, Al dalam bentuk dapat ditukarkan (Al-dd) umumnya terdapat pada tanah-tanah yang bersifat masam dengan $\mathrm{pH}<5,0$ Aluminium ini sangat aktif karena berbentuk $\mathrm{Al}^{3+}$ yang sangat merugikan dengan meracuni tanaman atau mengikat fosfor, oleh karena itu untuk mengukur sejauh mana pengaruh Al ini perlu ditetapkan kejenuhannya, semakin tinggi kejenuhan aluminium, akan semakin besar bahaya meracun terhadap tanaman, kandungan alumunium dapat tukar (Al3+) mempengaruhi jumlah bahan kapur yang diperlukan untuk 
meningkatkan kemasaman tanah dan produktivitas tanah (Anonimous, 2009), kadar aluminium sangat berhubungan dengan $\mathrm{pH}$ tanah, Semakin rendah $\mathrm{pH}$ tanah, maka semakin tinggi aluminium yang dapat dipertukarkan dan sebaliknya. Bila kejenuhan aluminium $>60 \%$, tanah tersebut sering dikatakan tidak layak untuk tanah pertanian sebelum direklamasi atau ameliorasi terlebih dahulu, Oleh karena kejenuhan aluminium dipengaruhi oleh KTK dan juga dipengaruhi oleh tekstur, maka semakin kasar tekstur tingkat kebahayaan aluminium semakin tinggi (Rosmarkam dan Yuwono, 2002), Hakim, dkk (1986) menyatakan bahwa keracunan aluminium menghambat perpanjangan dan pertumbuhan akar primer, serta menghalangi pembentukan akar lateral dan bulu akar, apabila pertumbuhan akar terganggu, serapan hara dan pembentukan senyawa organik tersebut akan terganggu, sistem perakaran yang terganggu akan mengakibatkan tidak efisiennya akar menyerap unsur hara. Hasil Penelitian analisa tanah di Desa Giri Agung KTK kebanyakan rendah, dan masam adapun KTK yang rendah dapat ditingkatkan dengan penggunaan pupuk organik yang berguna untuk meningkatkan tanah menjadi gembur dan daya jerap tanah dan untuk meningkatkan kapasitas tukar kation sehingga dapat menampung apabila dilakukan penambahan unsur hara baik secara alami maupun dengan penambahan pupuk (Datu BP et al. 2013). Selanjutnya pemupukan ditentukan oleh keadaan tanah seperti Tanah-tanah pada lokasi studi menunjukkan reaksi tanah agak masam perlu dilakukan pemberian kapur (I Gede EB et al.2017).

\section{C-organik, N-total dan P-tersedia}

Pengolahan dari data C-organik, $\mathrm{N}$-total dan P-tersedia yang telah didapatkan dilapangan menghasilkan nilai seperti yang tersaji pada tabel dibawah ini.

Tabel 3. Perbandingan Nilai C-organik, N-total dan P-tersedia Antara Lahan Original

\begin{tabular}{|c|c|c|c|c|c|}
\hline \multirow{3}{*}{ No } & \multicolumn{2}{|l|}{ Lapanean } & \multirow{2}{*}{ C-oreanik } & \multirow{2}{*}{ N-total } & 12205 \\
\hline & \multirow{2}{*}{ Kode } & \multirow{2}{*}{$\begin{array}{c}\text { interval } \\
\text { (cm) } \\
0-30\end{array}$} & & & \multirow{2}{*}{$\begin{array}{l}\text { Bray } 1 \\
\text { ppm }\end{array}$} \\
\hline & & & \multicolumn{2}{|c|}{$\%$} & \\
\hline 1 & \multirow{2}{*}{ BL335B2 (ORP.3000) } & $0-30$ & $1.14(R)$ & 0.09 (SR) & 1.86 (SR) \\
\hline 2 & & $30-60$ & $0.22(5 R)$ & $0.13(R)$ & $0.22(S R)$ \\
\hline 4 & (1) - & $30-60$ & $1 .>7(R)$ & 0.15 (R) & 1.36 (SR) \\
\hline 5 & RIOSSRT(RRP G8OO) & $0-30$ & $2.16(5)$ & $0.11(R)$ & $1.86(S R)$ \\
\hline 6 & ) & $30-60$ & $0.90(S R)$ & $0.11(R)$ & 1.86 (SR) \\
\hline 7 & RIASR (RRP 7000$)$ & $0-30$ & $0.90(S R)$ & $0.11(R)$ & $1.36(S R)$ \\
\hline 10 & BL145B2 (OF & $30-60$ & $1.27(R)$ & 0.05 (SR) & $0.72(S R)$ \\
\hline 11 & BIISSBZ (OF & $0-30$ & $0.90(S R)$ & 0.11 (R) & $2.50(S R)$ \\
\hline 12 & BLLOSBL (COR) & $30-60$ & 1.27 (R) & $0.11(R)$ & $4.27(S R)$ \\
\hline 13 & $P 135 S P(R R)$ & $0-30$ & 1.38 (R) & $0.07(S R)$ & 1.36 (SR) \\
\hline 14 & BLSSSBL (OR) & $30-60$ & $0.33(5 R)$ & $0.10(R)$ & $0.72(S R)$ \\
\hline
\end{tabular}

Keterangan : OR (Lahan Original Pra tambang), S (Sedang), R (Rendah), SR (Sangat Rendah) 
Tabel 4. Perbandingan Nilai C-organik, N-total, P-tersedia, Tinggi dan Diameter Antara Lahan Revegetasi

\begin{tabular}{|c|c|c|c|c|c|c|c|c|}
\hline \multirow{3}{*}{ No } & \multicolumn{2}{|l|}{ Lapangan } & \multirow{2}{*}{ C-organik } & \multirow{2}{*}{ N-total } & \multirow{3}{*}{$\begin{array}{c}\text { P205 } \\
\text { Bray } 1 \\
\text { ppm }\end{array}$} & \multirow{3}{*}{$\begin{array}{c}\text { Tinggi } \\
\mathbf{m} \\
\end{array}$} & \multirow{3}{*}{\begin{tabular}{|c|} 
Diameter \\
$\mathbf{c m}$ \\
\end{tabular}} & \multirow{3}{*}{$\begin{array}{l}\text { Keterangan } \\
\text { Pertumbuhan }\end{array}$} \\
\hline & \multirow{2}{*}{ Kode } & \multirow{2}{*}{$\begin{array}{c}\text { Interval } \\
(\mathrm{cm})\end{array}$} & & & & & & \\
\hline & & & & $\%$ & & & & \\
\hline 1 & BL05SB1 (PT P.3000) & $0-30$ & 0.44 (SR) & 0.08 (SR) & $1.86(\mathrm{SR})$ & & & \multirow{2}{*}{ Tidak Normal } \\
\hline 2 & & $30-60$ & $1.27(R)$ & $0.10(R)$ & $0.22(\mathrm{SR})$ & & & \\
\hline 3 & BL03SB1 (PT P.6800) & $0-30$ & $0.44(\mathrm{SR})$ & $0.10(R)$ & $2.50(\mathrm{SR})$ & \multirow{2}{*}{2.70} & \multirow{2}{*}{4.77} & \multirow{2}{*}{ Tidak Normal } \\
\hline 4 & & $30-60$ & $0.90(\mathrm{SR})$ & $0.10(\mathrm{R})$ & $1.86(\mathrm{SR})$ & & & \\
\hline 5 & \multirow{2}{*}{ BL12SB1 (PT P.4500) } & $0-30$ & $0,52(\mathrm{SR})$ & $0,06(S R)$ & $1,90(\mathrm{SR})$ & \multirow{2}{*}{13.56} & \multirow{2}{*}{22.29} & \multirow{2}{*}{ Normal } \\
\hline 6 & & $30-60$ & $0,76(S R)$ & $0,08(S R)$ & $2,40(\mathrm{SR})$ & & & \\
\hline
\end{tabular}

Keterangan : PT (Lahan Revegetasi Pasca Tambang), R (Rendah), SR (Sangat Rendah)

Berdasarkan hasil analisis sampel tanah di Laboratorium Tanah Pusat Studi Reboisasi Hutan Tropika Humida Unmul Samarinda seperti yang disajikan pada tabel 4 dan 5 nilia C-organik, N-total pada lahan original pra tambang dan lahan revegetasi pasca tambang baik pada kedalaman 0-30 maupun 30-60 cm menurut Petunjuk Teknis Evaluasi Kesuburan Tanah dari Balitanah Bogor (2005) tergolong rendah sampai sangat rendah, C-organik (1,77-0,33 \%) dan $\mathrm{N}$ total $(0,18-0,05 \%)$ kecuali pada lahan original di Blok 05 dan 03 tergolong sedang, Sedangkan P-tersedia pada lahan original pra tambang dan lahan revegetasi pasca tambang baik pada kedalaman 0-30 maupun 30-60 cm keseluruhan tergolong sangat rendah $(4,27-0,22 \%)$ ini diakibatkan oleh sangat tingginya kejenuhan aluminium yang dapat mengikat fosfor.Berdasarkan dari data yang telah didaptkan menurut peneliti jenis tanamn Jabon (Anthocephalus cadamba) juga toleran terhadap Corganik, N-total dan P-tersedia yang menpunyai niali ekstrim yang dibuktikan normalnya pertumbuhan tanaman pada lahan revegetasi pasca tambang blok 12 dan pada lahan original pra tambang, adapun pada blok 05 khususnya blok 03 yang pertumbuhannya tidak normal diindikasikan ada faktor lain selain sifat kimia tanahnya.
C-organik secara kimiawi merupakan bagian yang mudah terurai melalui proses mineralisasi dan akan menyumbangkan sejumlah ion-ion hara ke dalam tanah (Hanafiah 2005), N-total jika sangat rendah akan menyebabkan tanaman kerdil, pertumbuhan tidak normal, warna daun kekuning-kuningan, daun mati, buah tidak sempurna cepat masak dan kadar protein menjadi rendah, P-tersedia merupakan unsur hara primer yang dibutuhkan oleh tanaman, fungsi yang paling penting adalah keterlibatannya dalam penyimpanan dantransfer energi di dalam tanaman, kekahatan $\mathrm{P}$ akan mengahambat prosesproses seperti pembelahan sel, pengembangan sel, respirasi dan fotosintesis, tanaman yang kekurangan $\mathrm{P}$ akanmenunjukkan gejala seperti pertumbuhan terhambat kerdil dan daundaunmenjadi ungu atau coklat dimulai dari ujung daun, gejala kekurangan $\mathrm{P}$ akantampak jelas pada tanaman yang masih muda.

Basa-Basa Dapat Ditukar $\left(\mathrm{Ca}^{2+}, \mathrm{Mg}^{2+}\right.$, $\mathrm{K}^{+}, \mathrm{Na}^{+}$), KTK dan Kejenuhan Basa

Pengolahan dari data Basa-Basa Dapat Ditukar $\left(\mathrm{Ca}^{2+}, \mathrm{Mg}^{2+}, \mathrm{K}^{+}, \mathrm{Na}^{+}\right)$, KTK dan Kejenuhan Basa yang telah didapatkan dilapangan menghasilkan nilai seperti yang tersaji pada tabel dibawah ini. 
Tabel 5. Perbandingan Nilai $\mathrm{Ca}^{2+}, \mathrm{Mg}^{2+}, \mathrm{K}^{+}, \mathrm{Na}^{+}, \mathrm{KTK}$ dan Kejenuhan Basa Antara Lahan Original

\begin{tabular}{|c|c|c|c|c|c|c|c|c|}
\hline \multirow{3}{*}{ No } & \multicolumn{2}{|l|}{ Lapangan } & \multicolumn{4}{|c|}{ Kation Basa (Nh4O-Ac) pH.7 } & \multirow{2}{*}{ KTK } & \multirow{3}{*}{$\begin{array}{c}\begin{array}{c}\text { Kejenuha } \\
\text { n Basa }\end{array} \\
\%\end{array}$} \\
\hline & \multirow{2}{*}{ Kode } & \multirow{2}{*}{\begin{tabular}{|c|} 
Interval \\
$(\mathrm{cm})$
\end{tabular}} & $\mathbf{K}+$ & $\mathrm{Na}+$ & Mg++ & Ca++ & & \\
\hline & & & \multicolumn{5}{|c|}{ meq/100 gr } & \\
\hline 1 & \multirow{2}{*}{ BL33SB2 (OR P.3000) } & $0-30$ & $0.10(R)$ & $0.01(\mathrm{SR})$ & $0.14(S R)$ & $0.06(S R)$ & $4.97(\mathrm{SR})$ & $6.16(S R)$ \\
\hline 2 & & $30-60$ & $0.08(\mathrm{SR})$ & $0.01(\mathrm{SR})$ & $0.04(\mathrm{SR})$ & $0.04(S R)$ & $5.91(R)$ & $2.73(\mathrm{SR})$ \\
\hline 3 & \multirow{2}{*}{ BL05SB1 (OR P.3000) } & $0-30$ & $0.16(R)$ & $0.01(\mathrm{SR})$ & $0.25(\mathrm{SR})$ & $0.14(\mathrm{SR})$ & $8.73(\mathrm{R})$ & $6.51(\mathrm{SR})$ \\
\hline 4 & & $30-60$ & $0.15(\mathrm{R})$ & $0.01(\mathrm{SR})$ & $0.12(\mathrm{SR})$ & $0.05(\mathrm{SR})$ & $9.58(R)$ & $3.49(\mathrm{SR})$ \\
\hline 5 & \multirow{2}{*}{ BLO3SB1 (OR P.6800) } & $0-30$ & $0.12(\mathrm{R})$ & $0.01(S R)$ & $0.06(\mathrm{SR})$ & $0.05(\mathrm{SR})$ & $6.75(\mathrm{R})$ & $3.69(\mathrm{SR})$ \\
\hline 6 & & $30-60$ & $0.13(R)$ & $0.01(\mathrm{SR})$ & $0.05(\mathrm{SR})$ & $0.07(S R)$ & $7.76(\mathrm{R})$ & $3.36(\mathrm{SR})$ \\
\hline 7 & \multirow{2}{*}{ BL14SB2 (OR P.7000) } & $0-30$ & $0.10(R)$ & $0.01(S R)$ & $0.06(\mathrm{SR})$ & $0.06(S R)$ & $8.32(\mathrm{R})$ & $2.80(\mathrm{SR})$ \\
\hline 8 & & $30-60$ & $0.13(\mathrm{R})$ & $0.01(S R)$ & $0.03(\mathrm{SR})$ & $0.04(\mathrm{SR})$ & $9.96(R)$ & $2.08(\mathrm{SR})$ \\
\hline 9 & \multirow{2}{*}{ BL14SB2 (OR P.3000) } & $0-30$ & $0.08(\mathrm{SR})$ & $0.01(\mathrm{SR})$ & $0.09(\mathrm{SR})$ & $0.06(S R)$ & $4.57(\mathrm{SR})$ & $5.08(\mathrm{SR})$ \\
\hline 10 & & $30-60$ & $0.07(S R)$ & $0.01(S R)$ & $0.03(\mathrm{SR})$ & $0.04(S R)$ & $3.31(\mathrm{SR})$ & $4.41(\mathrm{SR})$ \\
\hline 11 & \multirow{2}{*}{ BL18SB2 (OR) } & $0-30$ & $0.07(S R)$ & $0.01(S R)$ & $0.04(\mathrm{SR})$ & $0.07(\mathrm{SR})$ & $3.52(\mathrm{SR})$ & $5.42(\mathrm{SR})$ \\
\hline 12 & & $30-60$ & $0.07(\mathrm{SR})$ & $0.01(S R)$ & $0.06(S R)$ & $0.07(S R)$ & $3.04(S R)$ & $6.89(\mathrm{SR})$ \\
\hline 13 & \multirow{2}{*}{ BL35SB2 (OR) } & $0-30$ & $0.11(R)$ & $0.02(\mathrm{SR})$ & $0.10(\mathrm{SR})$ & $0.20(S R)$ & $5.26(\mathrm{R})$ & $8.11(\mathrm{SR})$ \\
\hline 14 & & $30-60$ & $0.12(R)$ & $0.01(\mathrm{SR})$ & $0.07(\mathrm{SR})$ & $0.10(\mathrm{SR})$ & $5.88(R)$ & $5.07(\mathrm{SR})$ \\
\hline
\end{tabular}

Keterangan : PT (Lahan Revegetasi Pasca Tambang) R (Rendah), SR (Sangat Rendah)

Tabel 6. Perbandingan NilaiCa2+, Mg2+, K+, Na+, KTK, Kejenuhan Basa, Tinggi dan Diameter Antara Lahan Revegetasi

\begin{tabular}{|c|c|c|c|c|c|c|c|c|c|c|c|}
\hline \multirow{3}{*}{ No } & \multicolumn{2}{|l|}{ Lapangan } & \multicolumn{4}{|c|}{ Kation Basa (Nh4O-Ac) pH.7 } & \multirow{3}{*}{ KTK } & \multirow{3}{*}{\begin{tabular}{|c|}
$\begin{array}{c}\text { Kejenuhan } \\
\text { Basa }\end{array}$ \\
$\%$ \\
\end{tabular}} & \multirow{3}{*}{$\begin{array}{c}\text { Tinggi } \\
\mathbf{m} \\
\end{array}$} & \multirow{2}{*}{ Diameter } & \multirow{3}{*}{$\begin{array}{l}\text { Keterangan } \\
\text { Pertumbuhan }\end{array}$} \\
\hline & \multirow{2}{*}{ Kode } & \multirow{2}{*}{$\begin{array}{c}\text { Interval } \\
(\mathrm{cm})\end{array}$} & $\mathbf{K +}$ & $\mathrm{Na}+$ & Mg++ & $\mathrm{Ca}++$ & & & & & \\
\hline & & & \multicolumn{4}{|c|}{$\mathrm{meq} / 100 \mathrm{gr}$} & & & & $\mathrm{cm}$ & \\
\hline$\frac{1}{2}$ & BL05SB1 (PT P.3000) & $0-30$ & $0.15(R)$ & $0.01(\mathrm{SR})$ & 0.19 (SR) & 0.15 (SR) & $4.50(\mathrm{SR})$ & 11.19 (SR) & & & Tidak Normal \\
\hline 3 & \multirow{2}{*}{ BL03SB1 (PT P.6800) } & $0-30$ & $0.13(R)$ & $0.01(\mathrm{SR})$ & $0.45(R)$ & $0.27(S R)$ & $6.12(R)$ & $14.15(\mathrm{SR})$ & \multirow{2}{*}{2.70} & \multirow{2}{*}{4.77} & \multirow{2}{*}{ Tidak Normal } \\
\hline 4 & & $30-60$ & $0.11(\mathrm{R})$ & $0.01(\mathrm{SR})$ & $0.41(\mathrm{R})$ & $0.26(\mathrm{SR})$ & $5.87(\mathrm{R})$ & $22.06(\mathrm{R})$ & & & \\
\hline
\end{tabular}

Keterangan : PT (Lahan Revegetasi Pasca Tambang) S (Sedang), R (Rendah), SR (Sangat Rendah), T (Tinggi)

Basa-basa yang dapat dipertukarkan, KTK, kejenuhan basa dan $\mathrm{pH}$ tanah saling berhubungan, Basa-basa yang dapat dipertukarkan adalah total kation-kation basa dari ion $\left(\mathrm{Ca}^{2+}, \mathrm{Mg}^{2+}\right.$, $\left.\mathrm{K}^{+}, \mathrm{Na}^{+}\right)$sedangkan kejenuhan basa adalah jumlah basa-basa tersebut per kapasitas tukar kation tanah dan dinyatakan dalam satuan persen, Jika kejenuhan basa tinggi maka $\mathrm{pH}$ tanah tinggi karena jika kejenuhan basa rendah berarti banyak terdapat kation-kation masam yang terjerap kuat di koloid tanah.

Pada daerah yang memiliki curah hujan tinggi, koloid tanah akan lebih banyak didominasi oleh ion $\mathrm{H}^{+}$, sedangkan kation-kation basa terjerap lemah dan berada pada larutan bebas (Hakim dkk, 1986), tingginya curah hujan mengakibatkan kandungan basabasa yang dapat dipertukarkan semakin rendah karena proses pencucian berjalan intesif, Pada lahan yang sering terbuka, seperti pada lahan-lahan revegetasi yang belum mempunyai penutupan tajuk juga akan menambah pemicu terjadinya leaching, hal ini akan dapat menyebabkan penurunan kandungan kation basa di dalam tanah.

Berdasarkan hasil analisis sampel tanah di Laboratorium Tanah Pusat Studi Reboisasi Hutan Tropika Humida Unmul Samarinda seperti yang disajikan pada tabel 6 dan 7 nilia basa-basa dapat dipertukarkan $\left(\mathrm{Ca}^{2+}, \mathrm{Mg}^{2+}, \mathrm{K}^{+}, \mathrm{Na}^{+}\right)$pada lahan original pra tambang dan lahan revegetasi pasca tambang keseluruhan tergolong rendah sampai sangat rendah, 
$\mathrm{Ca}^{2+}\left(1,29-0,32\right.$ meq/100 gr), $\mathrm{Mg}^{2}(0,85-$ $0,03 \mathrm{meq} / 100 \mathrm{gr}), \mathrm{K}^{+}(0,16-0,07 \mathrm{meq} / 100$ gr), $\mathrm{Na}^{+}(0,02-0,00)$, kecuali nilai $\mathrm{Mg}^{2+}$ pada kedalaman 30-60 cm tegolong sedang dengan nilai $(1,89 \mathrm{meq} / 100 \mathrm{gr})$, diperkirakan nilai inilah yang memicu kenaik kejenuhan basa hinga tergolong tinggi dengan nilai $(63.57 \%)$

Adapun kapasitas tukar kation (KTK) pada lahan original pra tambang dan lahan revegetasi pasca tambang baik pada kedalaman 0-30 maupun 30-60 cm menurut Petunjuk Teknis Evaluasi Kesuburan Tanahdari Balitanah Bogor (2005) tergolong rendah sampai sangat rendah (9,58-3,04 meq/100 gr).

Untuk kejenuhan basa pada lahan original pra tambang dan lahan revegetasi pasca tambang baik pada kedalaman 0-30 maupun 30-60 cm menurut Petunjuk Teknis Evaluasi Kesuburan Tanah dari Balitanah Bogor (2005) keseluruhannya tergolong sangat rendah (14,15-2,08 \%) terkecuali pada Blok 12 yang tergolong rendah $(22,06 \%)$ pada kedalaman 0-30 $\mathrm{cm}$ dan tergolong tinggi $(63,57 \%)$ pada kedalaman 30-60 $\mathrm{cm}$ kondisi ini dapat dipicu dengan nilai $\mathrm{Mg}^{2+}$ pada kedalaman $30-60 \mathrm{~cm}$ tegolong sedang dengan nilai (1,89 meq/100 gr).

Kondisi sifat kimia basa-basa dapat ditukar $\left(\mathrm{Ca}^{2+}, \mathrm{Mg}^{2+}, \mathrm{K}^{+}, \mathrm{Na}^{+}\right)$diatas sejalan dengan pendapt beberapa pakar dan pada daerah penelitian di Kabupaten Kutai Barat termasuk dalam kategori iklim tropika humida dengan rata-rata curah hujan yang tinggi sehinga proses pencucian berjalan intesif menyebabkan basa-basa yang dapat dipertukarkan tergolong rendah hingga sangat rendah baik pada lahan original pra tambang maupun pada lahan revegetasi pasca tambang, kecuali pada Blok 12 lahan revegetasi pasca tambang hanya nilai $\mathrm{Mg}$ yang tergolong sedang, diperkirkan itu mampu memicu kejenuhan basa hingga tergolong tinggi sehingga dapat membantu pertumbuhan tanaman jenis Jabon (Anthocephalus cadamba) lebih baik dibandingkan pada Blok 03 yang mempunyai nilai kejenuhan basa yang sangat rendah.

Kapasitas tukar kation tanah didefinisikan sebagai kapasitas tanah untuk menyerap dan mempertukarkan kation, Kation-kation yang berbeda dapat mempunyai kemampuan yang berbeda untuk menukar kation yang dijerap, Kapasitas tukar kation merupakan sifat kimia yang sangat erat hubungannya dengan kesuburan tanah, KTK pada lokasi penelitian tergolong sangat rendah, ini menunjukkan bahwa tanahnya tidak mampu menyerap dan menyediakan unsur hara diduga karena unsur-unsur hara tersebut hilang tercuci oleh air.

Jika melihat dari data analisis karakteristik sifat kimia tanah yang telah didapatkandiatas baik pada lahan origanl pra tambang dan lahan revegetasi pasca tambang, dari keseluruhan hanya nilai $\mathrm{Mg}^{2+}$ dan Kejenuhan Basa pada lahan revegetasi pasca tambang di blok 12 yang kondisinya terbaik untuk tanaman menurut Balitanah Bogor (2005), Akan tetapi nilai sifat kimia tanah pada daerah penelitian didominasi oleh kondisi yang ekstrim bagi tanaman sehingga peneliti berpendapat jenis tanaman Jabon (Anthocephalus cadamba) toleran terhadap sifat-sifat kimia tanah yang ekstirm.

Tekstur

Pengolahan dari data tekstur yang telah didapatkan dilapangan menghasilkan nilai seperti yang tersaji pada tabel dibawah ini. 
Tabel 7. Perbandingan Nilai Tekstur, Tinggi dan Diameter Antara Lahan Revegetasi

\begin{tabular}{|c|c|c|c|c|c|c|c|c|c|}
\hline \multirow{3}{*}{ No } & \multicolumn{2}{|l|}{ Lapangan } & \multicolumn{3}{|c|}{ Penyebaran Partikel } & \multirow{3}{*}{ Tekstur } & \multirow{4}{*}{$\begin{array}{c}\text { Tinggi } \\
\mathbf{m} \\
\end{array}$} & \multirow{3}{*}{\begin{tabular}{|c|} 
Diameter \\
$\mathbf{c m}$ \\
\end{tabular}} & \multirow{3}{*}{$\begin{array}{c}\text { Keteragan } \\
\text { Pertumbuha } \\
\text { n }\end{array}$} \\
\hline & \multirow{2}{*}{ Kode } & \multirow{2}{*}{$\begin{array}{c}\text { Interval } \\
(\mathrm{cm})\end{array}$} & Silt & Clay & Total Sand & & & & \\
\hline & & & & $\%$ & & & & & \\
\hline \multirow{2}{*}{$\frac{1}{2}$} & \multirow{2}{*}{ BL05SB1 (PT P.3000) } & $0-30$ & 21.90 & 24.60 & 53.50 & $\mathrm{SCL}$ & & & Tidak \\
\hline & & $30-60$ & 30.10 & 25.80 & 44.10 & Loam & & & Normal \\
\hline \multirow{2}{*}{\begin{tabular}{l|l}
3 \\
4
\end{tabular}} & \multirow{2}{*}{ BLO3SB1 (PT P.6800) } & $0-30$ & 29.80 & 30.00 & 40.20 & $\mathrm{CL}$ & \multirow{2}{*}{2.70} & \multirow{2}{*}{4.77} & Tidak \\
\hline & & $30-60$ & 32.40 & 28.40 & 39.20 & $\mathrm{CL}$ & & & Normal \\
\hline \multirow{2}{*}{5} & \multirow{2}{*}{ BL12SB1 (PT P.4500) } & $0-30$ & 15,50 & 30,00 & 54,50 & $\mathrm{SCL}$ & \multirow{2}{*}{13.56} & \multirow{2}{*}{22.29} & \multirow{2}{*}{ Normal } \\
\hline & & $30-60$ & 13,40 & 28,10 & 58,50 & $\mathrm{SCL}$ & & & \\
\hline
\end{tabular}

Keteangan : PT (Lahan Revegetasi Pasca Tambang), Silt (Debu), Clay (Liat), Sand (Pasir), CL (Lempung Berliat), Loam (Lempung)

Tabel 8. Perbandingan Nilai Tekstur Antara Lahan Original

\begin{tabular}{|c|c|c|c|c|c|c|}
\hline \multirow{3}{*}{ No } & \multicolumn{2}{|l|}{ Lapangan } & \multicolumn{3}{|c|}{ Penyebaran Partikel } & \multirow{3}{*}{ Tekstur } \\
\hline & \multirow{2}{*}{ Kode } & \multirow{3}{*}{$\begin{array}{l}\text { Interval } \\
\text { (cm) } \\
0-30\end{array}$} & Silt & Clay & Total Sand & \\
\hline & & & \multicolumn{3}{|r|}{ 年 } & \\
\hline 1 & BL33SB2 (ORP 3000$)$ & & 29.80 & 24.00 & 46.20 & Loam \\
\hline 2 & (0) & $30-60$ & 17.90 & 29.10 & 53.00 & SCL \\
\hline \multirow{2}{*}{3} & \multirow{2}{*}{ BLOSSB1 (ORP.3000) } & $0-30$ & 35.70 & 30.10 & 34.20 & CL \\
\hline & & $30-60$ & 36.50 & 38.40 & 25.10 & CL \\
\hline \multirow{2}{*}{5} & \multirow{2}{*}{ BLO3SB1 (ORP.6800) } & $0-30$ & 58.70 & 30.10 & 11.20 & SiCL \\
\hline & & $30-60$ & 50.10 & 34.00 & 15.90 & SiCL \\
\hline \multirow{2}{*}{7} & \multirow{2}{*}{ BL14SB2 (ORP. 7000) } & $0-30$ & 36.70 & 33.30 & 30.00 & CL \\
\hline & & $30-60$ & 33.10 & 41.60 & 25.30 & CIay \\
\hline \multirow{2}{*}{9} & \multirow{2}{*}{ BLI4SB2 (ORP.3000) } & $0-30$ & 24.90 & 16.50 & 58.60 & SL \\
\hline & & $30-60$ & 36.50 & 13.10 & 50.40 & Loam \\
\hline \multirow{2}{*}{$\frac{11}{12}$} & \multirow{2}{*}{ BL18SB2 (OR) } & $0-30$ & 27.00 & 10.30 & 62.70 & SL \\
\hline & & $30-60$ & 19.70 & 8.50 & 71.80 & SL \\
\hline 13 & \multirow{2}{*}{ BL35SB2 (OR) } & $0-30$ & 6.70 & 35.40 & 57.90 & sc \\
\hline 14 & & $30-60$ & 6.90 & 25.20 & 67.90 & SCL \\
\hline
\end{tabular}

Keteangan : OR (Original/Lahan original Pra Tambang), Silt (Debu), Clay (Liat), Sand (Pasir), CL (Lempung Berliat), Loam (Lempung), SCL (Lempung Liat Berpasir), SL (Pasir Berlempung)

Berdasarkan hasil analisis sampel tanah di Laboratorium Tanah Pusat Studi Reboisasi Hutan Tropika Humida Universitas Mulawarman Samarinda seperti yang disajikan pada tabel 8 dan 9 hasil analisis tekstur tanah pada lahan revegetasi pasca tambang dan lahan original pra tambang baik pada kedalaman 0-30 maupun 30-60 cm menurut Petunjuk Teknis Evaluasi Kesuburan Tanah dari Balitanah Bogor (2005) yang mengacu pada soil taxonomy, USDA (Soil Survey Staff, 1990) menunjukkan bahwa tanah didaerah penelitian didominasi tekstur lempung berliat (clay loamy) dan lempung liat berpasir (sandy clay Loam), Meski kandungan lempung berliat yang tinggi tetapi nilai kapasitas tukar kation (KTK) tergolong rendah sampai sangat rendah, diperkirakan hal ini desebabkan oleh tanah tua jenis (Ultisol) pada daerah penelitian yang telah mengalami pencucian yang lama akibat curah hujan yang tinggi sehingga ketersediaan mineral basanya menipis.
Dikareanakan kapasitas tukar kation tanah didefinisikan sebagai kapasitas tanah untuk menyerap dan mempertukarkan kation, Kation-kation yang berbeda dapat mempunyai kemampuan yang berbeda untuk menukar kation yang dijerap, Kapasitas tukar kation merupakan sifat kimia yang sangat erat hubungannya dengan kesuburan tanah, KTK pada lokasi penelitian tergolong rendah hingga sangat rendah, ini menunjukkan bahwa tanahnya tidak mampu menyerap dan menyediakan unsur hara diduga karena unsur-unsur hara tersebut hilang tercuci oleh air.

\section{KESIMPULAN}

Berdasarkan penelitian dan pembahasan dapat disimpulkan bahwa 1) Karakteristik sifat kimia tanah pada lahan original pra tambang dilokasi penelitian pada umumnya mempunyai nilai $\mathrm{pH}$ yang sangat rendah berkisar antara (4,12-3,71 $\mathrm{H}_{2} \mathrm{O}$ ), C-organik sedang hingga sangat 
rendah berkisar antara $(2,42-0,22 \%)$, nitrogen rendah hingga sangat rendah berkisar antara $(0,18-0,05 \%)$,fosfor sangat rendah berkisar antara $(4,27-0,22)$ ppm), kalium rendah hingga sangat rendah berkisar antara $(0,15-0,07$ meq/100 gr), natrium sangat rendah berkisar antara (0,02-0,01 meq/100 gr),magnesium rendah hingga sangat rendah berkisar antara $(0,25-0,03$ meq/100 gr), kalsium sangat rendah berkisar antara $(0,14-0,04 \mathrm{meq} / 100 \mathrm{gr})$, kapasitas tukar kation sangat rendah berkisar antara (9,96-3,04 meq/100 gr), kejenuhan basa sangat rendah berkisar antara (8,11-2,08 \%) dan kejenuhan aluminium yang tinggi hingga sangt tinggi berkisar antar (56,59-72,26 \%). Berdasarkan data yang didapatkan menurut peneliti tanaman jenis Jabon (Anthocephalus cadamba) toleran dan dapat hidup terhadap karakteristik sifat kimia diatas tapi tidak dengan kejunahan basa yang sangat rendah. 2)Adapun sifat kimia tanah pada lahan revegetasi pasca tambang dilokasi penelitian baik pada tanaman yang mengalami ketidaknormalan pertumbuhan dan yang pertumbuhanya normal tidak memiliki perbedaan yang signifikan kecuali magnesium yang mempunyai nilai tergolong sedang dan kejenuhan basa mempunyai nilai yang tergolong tinggi pada tanaman yang pertumbuhanya normal, berikut rinciannya nilai $\mathrm{pH}$ berkisar antara $\left(4,09-4,53 \quad \mathrm{H}_{2} \mathrm{O}\right)$, CorganiK berkisar antara $(0,44-1,27 \%)$, nitrogen berkisar antara $(0,08-0,10 \%)$, fosfor berkisar antara (0,22-2,50 ppm), kalium berkisar antara $(0,11-0,15$ meq/100 gr), natrium berkisar antara (0,00-0,02 meq/100 gr), magnesium berkisar antara (0,15-1,89 meq/100 gr), kalsium berkisar antara (0,05-1,29 meq/100 gr), KTK berkisar antara (4,506,12 meq/100 gr), dan kejenuhan aluminium berkisar antara $(23,76-76,83)$.

3) Sehingga penyebab utama dari ketidaknormalan pada lahan revegetasi pasca tambang untuk jenis pohon Jabon (Anthocephalus cadamba) di Blok 05 dan khususnya diBlok 03 terkait dengan sifat kimia tanahnya adalah sangat rendahnya kejenuhan basa adapun faktor lain yang sangat berpengaruh menurut peneliti adalah betuk lereng yang relatif datar dengan tekstur yang tegolong liat berlempung (clay loam) sehingga dapat meyebabkan air mengendap membuat akar membusuk.

\section{DAFTAR PUSTAKA}

EB, I. Gede, and Maya PB Jumani. "Evaluation of Soil Revegetation Success Rate Ex-Pit Coal Mine in Kitadin site Embalut Kutai in East Kalimantan." Agrifor 16.2 (2017): 195-208.

Hakim, dkk., 1986. Dasar-dasar Imu Tanah. Penerbit Universitas Lampung, Lampung.

Hanafiah, K. A. 2005. Dasar-Dasar Ilmu Tanah. PT Raja Grafindo Persada, Jakarta.

[Kemenhut] Departemen Kehutanan, 2009, Peraturan Menteri Kehutanan Republik Indonesia Nomor: P.60/Menhut-II/2009 tentang Pedoman Penilaian Keberhasilan Reklamasi Hutan. Jakarta: Kemenhut.

Pramana, Datu Bandar. "Pertumbuhan Tanaman Gaharu (Aquilaria sp.) di Desa Giri Agung Kecamatan Sebulu Kabupaten Kutai Kartanegara Provinsi Kalimantan Timur." AGRIFOR 11.2 (2013): 110-114.

Rosmarkam, A. dan N. W. Yuwono. 2002. Ilmu Kesuburan Tanah. Kanisius, Yogyakarta. 